\title{
Phylogenetic Characterization of BKH3 Bacterium Isolated from a Hot Spring Consortium of Bakreshwar (India) and Its Application
}

\author{
Biswadeep Chaudhuri, Nurul Alam, Manas Sarkar, Trinath Chowdhury, \\ Brajadulal Chattopadhyay* \\ Department of Physics, Jadavpur University, Kolkata, India \\ Email: bdc_physics@yahoo.co.in
}

Received 22 February 2016; accepted 13 May 2016; published 18 May 2016

Copyright @ 2016 by authors and Scientific Research Publishing Inc.

This work is licensed under the Creative Commons Attribution International License (CC BY). http://creativecommons.org/licenses/by/4.0/

(c) (i) Open Access

\section{Abstract}

Background: The silica leaching attribute of some of the mystifying bacteria present in the cluster of hot springs (temperatures range $35^{\circ} \mathrm{C}-80^{\circ} \mathrm{C}$ ) at Bakreshwar (West Bengal, India, $23^{\circ} 52^{\prime} 48 " \mathrm{~N}$; $\left.8^{\circ} 22^{\prime} 40^{\prime \prime}\right)$ has provided some significant advancements in construction technology when incorporated to the concrete/mortar specimens. The present investigation was designed to isolate other novel bacterial strains from $65^{\circ} \mathrm{C}$ hot spring that could have similar or better performance in construction technology. Methods: Soil sample collected from the $65^{\circ} \mathrm{C}$ hot spring was inoculated to the culture vials (incubated at $65^{\circ} \mathrm{C}$ ) containing a specific synthetic growth medium (pH 8.0) to grow the bacterial population anaerobically by degassing the medium with $\mathrm{CO}_{2}$ gas. Subsequent serial dilution techniques were employed to isolate pure culture of a specific bacterial strain. $16 \mathrm{~S}$ rRNA gene sequence and phylogenetic analysis was carried out to identify the novelty of the isolated bacterial strain. The isolated bacteria were incorporated to the cement sand mixture at various cell concentrations to evaluate the efficacy of the strain in construction technology. Results: The work revealed the presence of a novel bacterial strain (BKH3; GenBank Accession No.: KP 890928) within the same hot spring consortium whose $16 \mathrm{~S}$ rRNA gene sequence data showed $96 \%$ identity with Citrobacter freundii bacterial species. The newly isolated bacteria when incorporated at different cell concentration to the cement/cement-sand mixture were found to possess the similar compressive strength increment property, the cracks repairing ability and the water ingression resistivity. It also reduced the permeability of sulphate ions to the cementitious matrix reflecting the increment of durability of the incorporated material. Conclusions: The enhancement of compressive strength and durability of the as prepared bio-concrete material by using the isolated bacterial strain (BKH3) was due to the silica leaching activity of the bioremediase like pro-

\footnotetext{
Corresponding author.
}

How to cite this paper: Chaudhuri, B., Alam, N., Sarkar, M., Chowdhury, T. and Chattopadhyay, B. (2016) Phylogenetic Characterization of BKH3 Bacterium Isolated from a Hot Spring Consortium of Bakreshwar (India) and Its Application. Advances in Microbiology, 6, 453-461. http://dx.doi.org/10.4236/aim.2016.66044 
tein secreted by the bacterium. This may open up another vista of utilization of hot spring bacterium for beneficial purposes in construction technology.

\title{
Keywords
}

\author{
Bioconcrete, Compressive Strength, Hot Spring, 16S rRNA, Phylogenetic Analysis
}

\section{Introduction}

Various aspects of Bakreshwar hot springs were investigated since the middle of the $20^{\text {th }}$ century, but isolation and examination of the thermophilic microbial inhabitants in them did not start until the late 1950s [1]. Many thermophilic microorganisms were discovered, although the real complexity of microbial communities was envisaged when researches based on PCR amplification of the 16S rRNA genes were initiated. Thereafter, the possibility of cloning and sequencing the total environmental DNA, defined as metagenome, and the study of the genes rescued from the metagenomic archives and assemblies made possible to gain more comprehensive understanding of the microbial communities. In the last decade hot springs were found to be a source of thermophilic enzymes of industrial interest, encouraging further study of the poorly understood complex diversity of microbial life in these habitats [1] [2].

In recent years, the phenomena of recovery of mechanical property in concrete materials through the process of biomineralization of some specific microorganisms have become an interesting area to the researchers [3]-[5]. Some specific proteins of different microorganisms control the process of biomineralization and also direct the prevention or creation of mineral deposits [5] [6]. Several researchers had explored this concept of bio-mineralogy for the development of new bioconcrete material [7] [8], cleaning of concrete surfaces [9] and injected microorganisms to induce calcite precipitation in a concrete crack [10] [11]. Researchers have also shown that some specific thermophilic microorganisms isolated from Bakreshwar hot springs play an important role in the development of higher compressive strength and more durable bio-concrete material [8] [12]-[16]. There are two bacterial strains (BKH1 \& BKH2) already isolated and characterized from water of the $65^{\circ} \mathrm{C}$ hot spring consortium of Bakreshwar, India. The bacteria BKH1 (99\% homologous with Thermoanaerobactor thermohydrosulfuricus) and BKH2 (97\% homologous with Cupriavidus metallidurans) both are found efficacious for enhancement of compressive strength and overall concrete properties [13] [15] [16]. These two bacteria when grown in a special semisynthetic medium, secrete extracellular proteins which when applied in concrete mixtures enhanced the strength of the concrete [13] [15]. In the present study, the 16S rRNA gene sequence methodology was employed to identify another bacterium from the same consortium and to test the same concrete/mortar specimen to observe its applicability on the improvement of its strength. The investigation has revealed the presence, among a few other bacteria, of some novel nonmarine, thermophilic relatives thereof. Presence of other organisms in the same hot spring water with beneficial industrial application may also be presumed.

\section{Materials \& Methods}

\subsection{Reagents}

All the analytical grade chemicals used in this investigation were purchased from the Sigma, USA, Merck, Germany and Amresco, USA \& GE, USA. For concrete/mortar sample preparation ordinary Pozzolana cement 43 grade and standard Ennore sand were used [8].

\subsection{Collection of Sample}

Samples were collected from one of the hot springs (Agnikunda) at Bakreshwar. The surface temperature of the sediment varied between $66^{\circ} \mathrm{C}$ and $67^{\circ} \mathrm{C}$. The $\mathrm{pH}$ of the water was measured varying from 7.8 to 8.0 . The sediment contained $1.1 \%$ to $1.5 \%$ organic carbons and, interestingly, 280 to $422 \mathrm{~mol}$ of reducible Fe (III) and 280 to $600 \mathrm{~mol}$ of reduced iron per $\mathrm{g}$ of wet sediment [17]. The temperature of the water at the time was around $65^{\circ} \mathrm{C}$. 


\subsection{Culture}

A mixed population culture of bacteria found in the crude soil samples of the hot spring at Bakreshwar, West Bengal, India was estimated. The culture was grown in a sealed glass pressure vial containing a semi-synthetic growth medium anaerobically (in presence of $\mathrm{CO}_{2}$ atmosphere) as described earlier [18]. The growth medium consisted of $\mathrm{Fe}(\mathrm{OH})_{3}-0.1 \mathrm{M}, \mathrm{Na}_{2} \mathrm{HPO}_{4}-0.6 \mathrm{~g} / \mathrm{L}, \mathrm{KCl}-0.33 \mathrm{~g} / \mathrm{L}, \mathrm{Na}_{2} \mathrm{CO}_{3}-2.5 \mathrm{~g} / \mathrm{L}$, yeast extract- $0.02 \%$ and peptone- $0.5 \%$ ). The $\mathrm{pH}$ of the medium was kept at 8.0 and the temperature for optimum growth was maintained at $65^{\circ} \mathrm{C}$ temperature. The enrichment culture was obtained by subsequent sub culturing the mixed population culture. Serial dilution technique was employed to get purified bacterial strain from the enrichment culture.

\subsection{Isolation of Genomic DNA}

Bacterial genomic DNA was isolated by $\mathrm{CTAB} / \mathrm{NaCl}$ method from the purified culture [19]. A $1.5 \mathrm{~mL}$ of the saturated bacterial culture was centrifuged at $6000 \times \mathrm{g}$ for 5 minutes to collect the bacterial cell pellet. The cell pellet was then suspended in $567 \mu \mathrm{l}$ of TE buffer ( $10 \mathrm{~mm}$ Tris, $1 \mathrm{~mm}$ EDTA, pH 8). Thereafter, $30 \mu \mathrm{l}$ of $10 \%$ SDS and $3 \mu \mathrm{L}$ of $20 \mathrm{mg} / \mathrm{ml}$ Proteinase-K (Amresco) were added in the same. The solution was mixed thoroughly and incubated at $37^{\circ} \mathrm{C}$ for $1 \mathrm{~h} .100 \mu \mathrm{L}$ of $5 \mathrm{M} \mathrm{NaCl}$ and $80 \mu \mathrm{L}$ of CTAB/NaCl solution (Sigma) was added and incubated at $65^{\circ} \mathrm{C}$ for $10 \mathrm{~min}$ and centrifuged at $10,000 \times \mathrm{g}$ to remove cell wall debris, denatured proteins and polysaccharides. Extraction of total chromosomal DNA was done with an equal volume of a mixture of chloroform: isoamyl alcohol $(24: 1)$ at $10,000 \times$ g. The aqueous phase was again similarly extracted with phenol: chloroform: isoamyl alcohol mixture (25:24:1). DNA precipitation was done by adding 0.6 volume of 2-propanol and centrifuged at 12,000 $\times \mathrm{g}$ for $10 \mathrm{~min}$. The DNA pellet was then washed with $70 \%$ ethanol, dried and dissolved in $50 \mu \mathrm{l}$ autoclaved MilliQ water for sequencing purposes. The input DNA samples were quantitated using Qubit DNA quantitation assays (Thermo Scientific) that specifically quantitate dsDNA. The quality check of the DNA samples were done using Nano-Drop Spectrophotometer (Thermo Scientific) as well as using 0.8\% Agarose TAE gel stained with Ethidium Bromide. Lower 260/230 ratio of the samples indicates presence of contaminants such as carbohydrates and phenols that absorb at $230 \mathrm{~nm}$ but this doesn't antagonize during sequencing procedure. Samples were taken that had a 260/280 ratio of 1.84 and 260/230 ratio of 1.79 for sequencing purpose.

\subsection{PCR Amplification and 16 S rRNA Gene Sequencing for Phylogenetic Tree Construction}

The PCR (Veriti ${ }^{\circledR}$ Thermal Cycler, Applied Biosystems, USA) reaction mixture contained DNA: $1 \mu \mathrm{l}$ (50 ng) as template, 16S Forward Primer: $400 \mathrm{ng}, 16 \mathrm{~S}$ Reverse Primer: $400 \mathrm{ng}$, dNTPs (2.5 mM each) $4 \mu$ l, high fidelity DNA polymerase $1 \mu \mathrm{l}(3 \mathrm{U} / \mu \mathrm{l})$ and $10 \mu \mathrm{l}$ of $10 \times$ Taq DNA polymerase Assay Buffer with a reaction volume of $100 \mu \mathrm{l}$ and the PCR condition was $94^{\circ} \mathrm{C}$ for initial denaturation for 5 minutes, $94^{\circ} \mathrm{C}$ for $30 \mathrm{~s}, 55^{\circ} \mathrm{C}$ for $30 \mathrm{~s}, 72^{\circ} \mathrm{C}$ for $30 \mathrm{~s}$ (For these three temperatures the cycle was maintained at for 35 cycles) and finally $72^{\circ} \mathrm{C}$ for $7 \mathrm{~min}$. Partial amplification of the 16S rRNA gene was done by performing PCR with bacteria specific universal primers as:

27F-AGAGTTTGATCCTGGCTCAG and 1492 R-TACGGTTACCTTGTTACGACTT,

The genomic DNA was used as template for Ribo-typing and construction of phylogenetic tree. A $1.4 \mathrm{~kb}$ band was detected and used for sequencing in PCR. The PCR product was purified using ExoSAP IT (Affymetrix) and then sequenced with capillary sequencer (Applied Biosystems 3500, Genetic Analyser, USA) using the above mentioned primers. Sequencing reaction was performed using Big Dye Terminator Cycle sequencing Kit V3.1 (Applied Biosystems, USA) following the manufacturer's protocol. The partial 16S rRNA gene sequence of the isolated organism was compared by BLAST search analysis (http://www.blast.ncbi.nlm.nih.gov) with those available in the public databases. Thereafter, identification to the species level was determined by 16S rRNA gene sequence similarity of that of the prototype strain sequence in the GenBank (http://www.ncbi.nlm.nih.gov/genbank). Sequence alignment of the 16S rRNA gene fragment and comparison was performed using the multiple sequence alignment program CLUSTALX ( $\mathrm{v}$ 1.83) with default parameters and the data converted to PHYLIP format. The frequency with which a given branch found is recorded as the bootstrap proportion. This proportion was used as a measure of the reliability (within limitations) of individual branches in the optimal tree [20]. Through multiple alignment analysis several random samples were taken. Minor modifications in the alignment were done using the BIOEDIT sequence editor. Thereafter, uprooted phylogenetic tree was constructed using 
the neighbour-joining (NJ) method. TREEVIEW (Win 32) programme was used to display the phylogenetic relationship.

\subsection{Mortar Samples Preparation for Compressive Strength and Ultrasonic Pulse Velocity (UPV) Measurement}

Mortar cubes with a dimension of $70.6 \mathrm{~mm} \times 70.6 \mathrm{~mm} \times 70.6 \mathrm{~mm}$ were cast for controls. The isolated hot spring bacterium was incorporated to cement-sand mixture at four different cell concentrations $\left(10^{4}, 10^{5}\right.$ and $10^{6}$ cells/ $\mathrm{ml}$ water used) for the test sample preparation. The cement to sand ratio was maintained as 1:3 and water to cement ratio at 0.4 for all categories of samples. Five sample cubes each for all categories were prepared for the compressive strength and ultrasonic-pulse velocity (UPV) measurements. All of these sample cubes were removed from the moulds after $24 \mathrm{~h}$ and immersed under water for 28 days at room temperature for water curing purpose. Another set of samples were cured in air for 28 days. After 28 days of curing, the breaking load analysis was determined by compressive strength testing machine. Prior to the breaking load analysis, the ultrasonic-pulse velocity of each sample was measured by using Pundit Plus ultrasonic pulse velocity measurement machine (Pundit plus PC1007 UPV meter as per ASTM C597-02). The whole experiment was repeated twice. Average breaking load and UPV was determined by taking the average of ten samples from each category. The data are presented in respective histograms with mean $\pm \mathrm{SD}$.

\subsection{Water Absorption Measurement of Mortar Samples}

This test was performed according to the methods described by Neville [21]. The absorption of water of mortar samples prepared with or without incorporation of bacterial cells (as mentioned in the sample preparation section) was determined. The samples were dried at a constant temperature $\left(52^{\circ} \mathrm{C}\right)$ for $72 \mathrm{~h}$ and then the weight of the samples was taken. The samples were then immersed in water for $30 \mathrm{~min}$ and their weights were measured. Finally the samples were immersed for $24 \mathrm{~h}$ and their weights were measured again. The increase in mass as a percentage of the dry mass was recorded to determine the water absorption proficiency.

\subsection{Sulphate Resistance Test of Mortar Samples}

The mortar samples (as described earlier) were immersed in 5\% magnesium sulphate solution for a specified period. The $\mathrm{pH}$ of the solution was maintained at 7.0. The consequence of exposure to sulphate was estimated by calculating the increase in mass of the sample [22]. The test was carried out as per the guidance of ASTM C 1012.

\section{Results \& Discussion}

The 16S rRNA gene occurs in all living organisms, with the notable exception of viruses, and represents more than $80 \%$ of total bacterial RNA. The 16S rRNA gene includes interspersed conserved and variable regions, which makes it well suited for PCR amplification and sequencing. The isolated bacterial strain was purified to a pure culture by serial dilution technique on several times. The bacterium sample was processed for 16S rRNA gene sequence analysis for identification of the strain and to confirm its authenticity (Figure 1). The sequence data obtained from the clone showed closely homologous with 96\% identity with Citrobacter freundii (Figure 2). The $16 \mathrm{~S}$ gene sequence data also showed $88 \%$ identity with Aeromonas hydrophila with mixed profile. The 16S rRNA gene data has been submitted in GenBank and received the accession number as GenBank Accession No.: KP890928. The phylogenetic tree of the isolated bacterial species was constructed and shown in Figure 2. The morphology of the bacterium was coccoid and the isolate was Gram negative bacterium. Systematic identifications of the purified culture confirm that BKH3 bacterial strain is a novel species.

The bacterial cells from purified strain (BKH3) were mixed to cement-sand mixture at different cells concentrations for mortar sample preparation. More than 25\% of compressive strength increment was achieved by using the novel bacterial strain at a cell concentration of $10^{5}$ cells $\cdot \mathrm{ml}^{-1}$ of water used (Figure 3 and Figure 4). Similar increment of tensile strength ( $>20 \%)$ of the mortar samples was also observed by incorporating this bacterium (data not supplied). The bacterium was found to secrete bioremediase-like protein which similarly possessed the property of biosilicification as found in BKH1 and BKH2 bacterial species described earlier [13] [15]. It might, therefore, be inferred that the bioremediase like protein similarly produced new Gehlenite phase within 


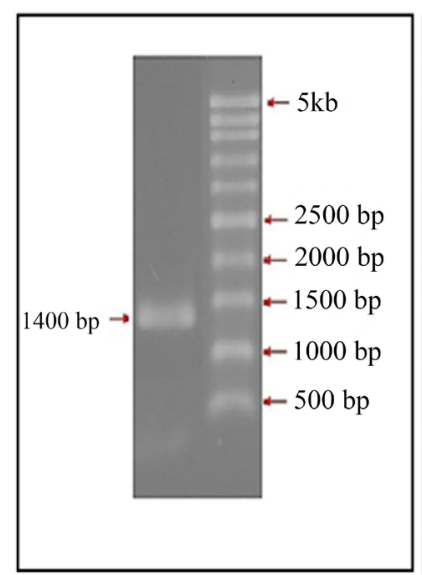

GTTCATTTTACATACGTAGAACTTGCTCTTGGGTGACGAGTGGCGGACGGGTGAGTAATGTCTGGGAAAC TGCCCGATGGAGGGGGATAACTACTGGAAACGGTAGCTAATACCGCATAACGTCGCAAGACCAAAGAGGG GGACCTTCGGGCCTCTTGCCATCGGATGTGCCCAGATGGGATTAGCTAGTAGGTGGGGTAACGGCTCACC TAGGCGACGATCCCTAGCTGGTCTGAGAGGATGACCAGCCACACTGGAACTGAGACACGGTCCAGACTCC TACGGGAGGCAGCAGTGGGGAATATTGCACAATGGGCGCAAGCCTGATGCACCCATGCCGCGTGTATGAA GAAGGCCTTCGGGTTGTAAAGTACTTTCAGCGAGGAGGAAGGCGTTGAGGTTAATAACCTTAGCCATTGA CGTTACTCGCAGAAAAAGCACCGGCTAACTCCGTGCCAGCAGCCGCGGTAATACGGAGGGTGCAAGCGTT AATCGGAATTACTGGGCGTAAAGCGCACGCAGGCGGTCTGTCAAGTCAGATGTGAAATCCCCGGGCTCAA CCTGGGAACTGCATCCGAAACTGGCAGGCTAGAGTCTTGTAGAGGGGGGTAGAATTCCAGGTGTAGCGGT GAAATGCGTAGAGATCTGGAGGAATACCGGTGGCGAAAGCGGCCCCCTGGACAAAGACTGACGCTCATGT GCGAAAGCATGGGGAGCAAACAAGATTATATACCCTGGTAGTCCACGCCGTATACGATGTCGACTTGGAG GTTGTGCCCTTGAGGCGTGGCTTCCGGAGCTAACGCGTTATTACACCGCCTGGGGAGTACGGCCGCAAGG TTAAACTCAAATGATTGACGGCGGGCCCGCACAGCGGGGGAGCATGTGTTTTATTTCGATGCAACGCGAA GAACCTTATCTGGTCTTGACATCCCACAGACTTACCAGAAATGATGTGGTGCCTTCGGAACTCTGAAGAC AGGTGCTGCATGTCTGTCCTCCGCCTCGTGTTGTGGATA

Figure 1. The sequence of the $1400 \mathrm{bp}$ band of PCR product of the isolated bacterium BKH3.

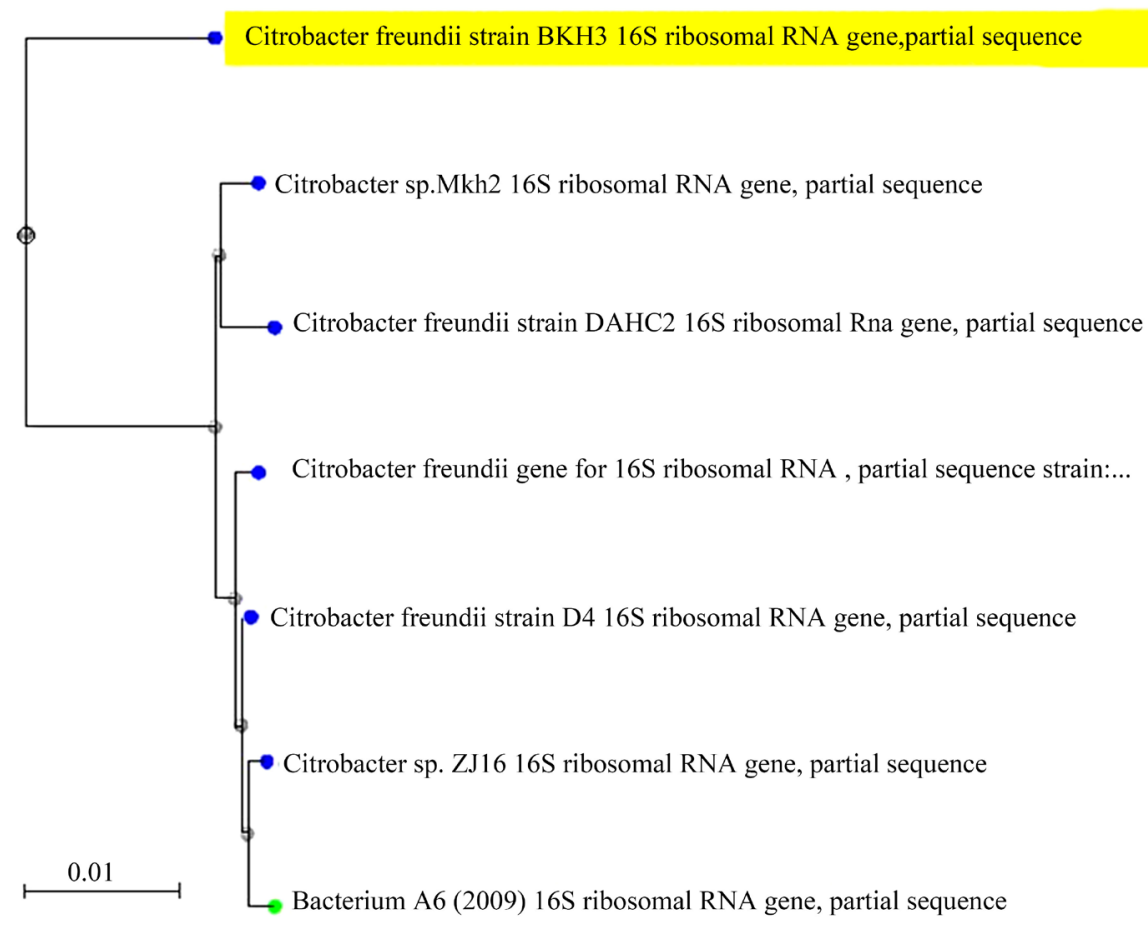

Figure 2. Phylogenetic tree for the isolated bacterium BKH3. Unrooted tree based on 16S rRNA sequence showing the phylogenetic relationships of Citrobacter freundii with its nearest neighbours.

the pores of the mortar matrices which took active role in enhancement of compressive strength and other properties of as prepared bio-concrete material as elaborately described in the previous publications [12] [15] [16]. Due to the variation of composition of the ingredients in concrete/mortar mixture, the compressive or tensile strengths vary to a certain extent (10\% maximum). But when the strength of the concrete/mortar is enhanced above $10 \%$ it becomes beneficial for construction. Significant improvement is observable when there is more than $20 \%$ enhancement in strength [8].

The crack repairing ability of the cracked mortar samples was also exhibited when the isolated bacterial cells were incorporated with the cement-sand mixture. The cracked samples repaired with bacterial cells in cementsand mixture exhibited higher compressive strength in comparison to the samples repaired with normal cement-sand mixture (Figure 5). It was also noted that the maximum crack repairing activity was occurred at the bacterial cells concentration of $10^{5} \mathrm{cell} / \mathrm{ml}$ water used. The enhanced hardness of the bacterial cells incorporated mortar samples was confirmed by the increased of ultrasonic-pulse velocity as seen from Figure 6 . The bacterium 


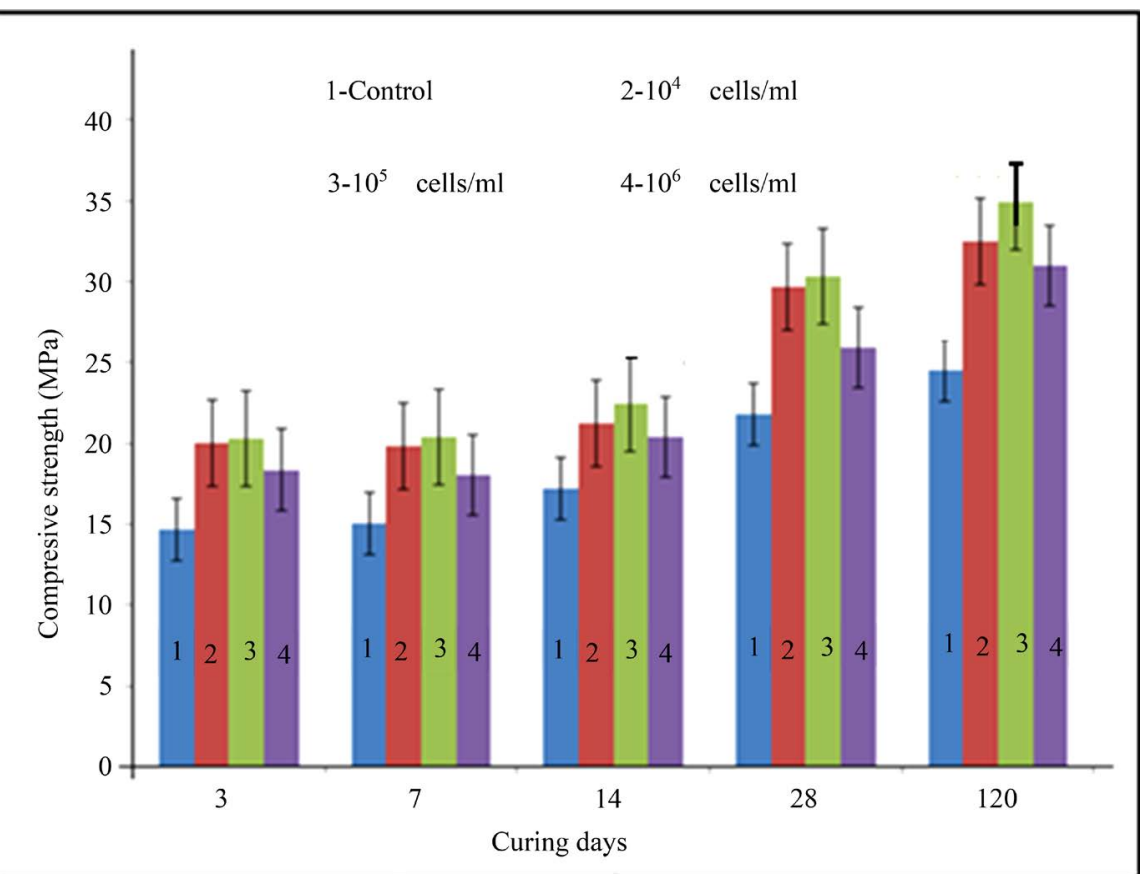

Figure 3. Compressive strengths of the BKH3 bacterial cells incorporated mortar samples at different days of air curing.

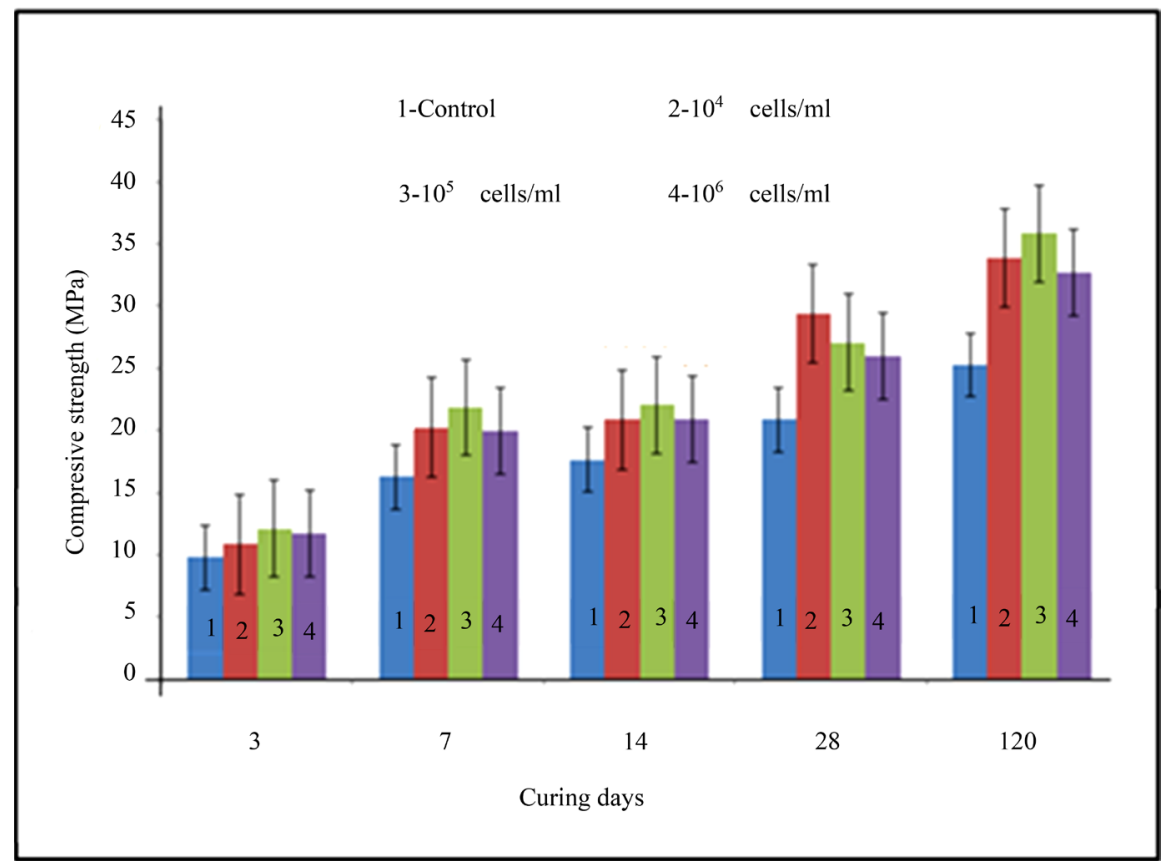

Figure 4. Compressive strengths of the BKH3 bacterial cells incorporated mortar samples at different days of water curing.

BKH3 also increased the durability of the incorporated mortar samples as reflected by the results of water absorption test (Table 1) and sulphate resistance test (Table 2). Interestingly, it was seen that the maximum durability attribute was developed at the bacterial cell concentration of $10^{5} \mathrm{cell} / \mathrm{ml}$ water used. In our previous studies, we have observed the strength increment as well as durability increment attributes of the bacterial strains (BKH1 and BKH2) isolated from hot spring at Bakreshwar. The present findings with the bacterium BKH3 also describe 


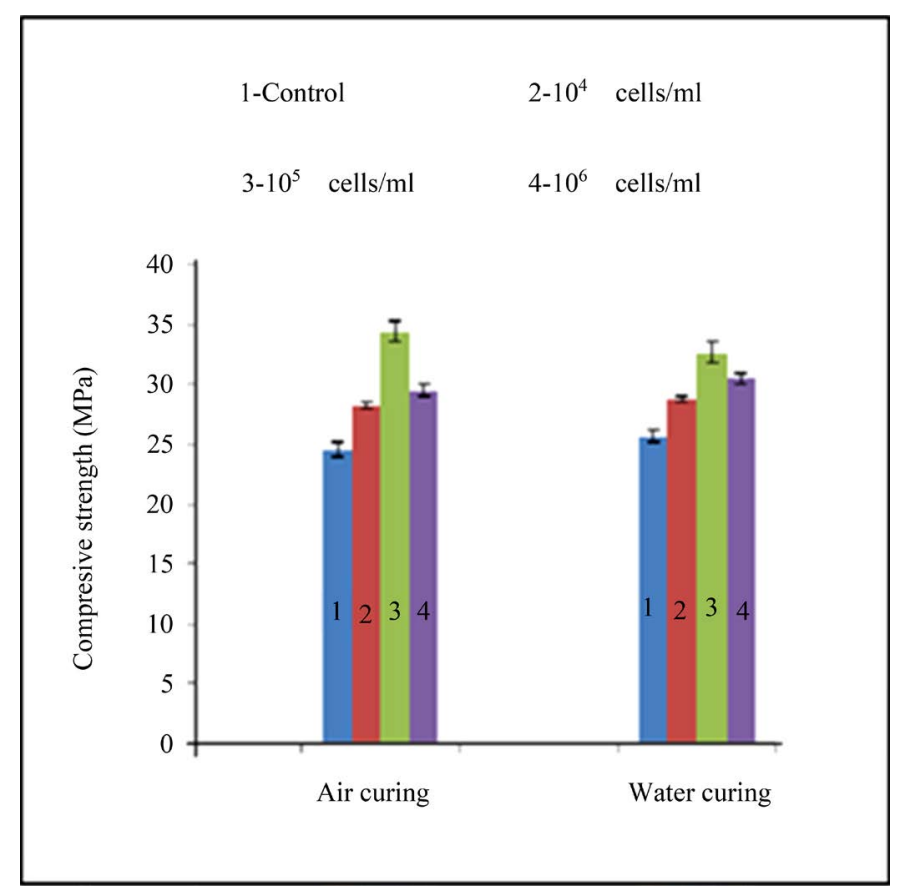

Figure 5. Compressive strengths of the cracked mortar samples when repaired with different BKH3 bacterial cells incorporated cement-sand mixture and cured under different conditions.

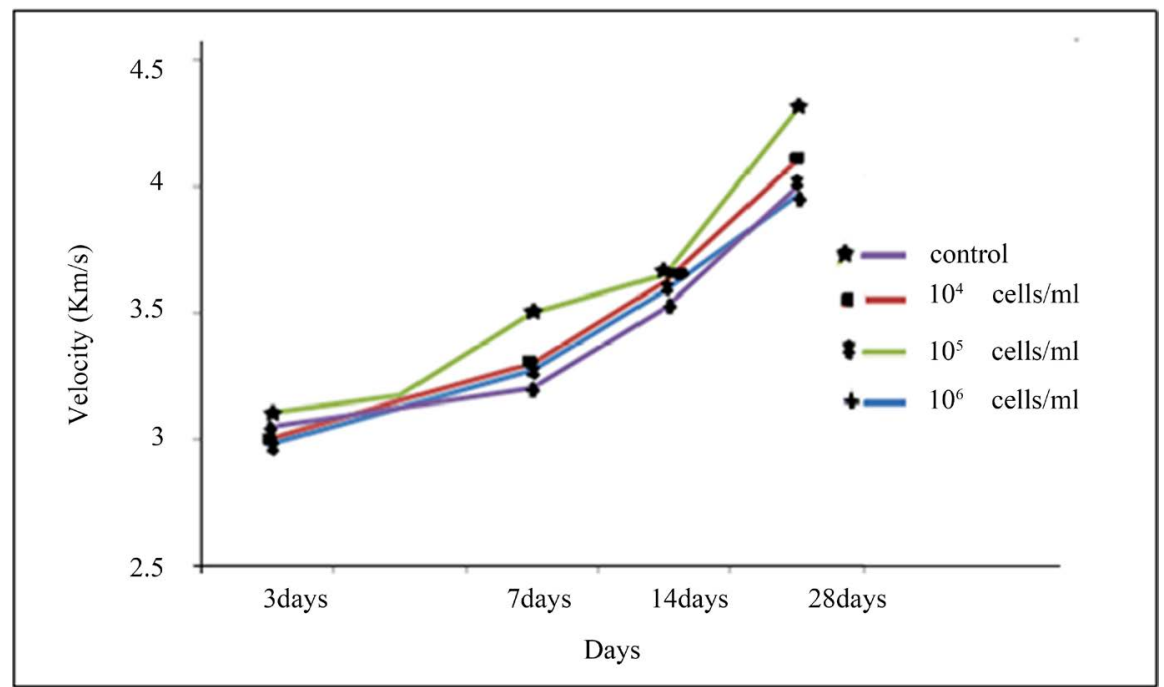

Figure 6. Ultrasonic Pulse Velocity test of the BKH3 cells incorporated mortar samples cured at different days under water.

similar phenomenon of hot spring bacteria. The aforesaid observed results confirm that the hot springs at Bakreshwar are rich sources of different bacterial strains which are found to have beneficial application in concrete industry.

\section{Conclusion}

The present investigation identifies a novel bacterium (BKH3) from the same hot spring (Temperature $65^{\circ} \mathrm{C}$ ) consortium. This has the property of enhancement in concrete strength. Plethora of thermophilic organisms with great industrial significance resides in these hot springs. More studies can then be looked in for understanding 
Table 1. Water absorption (28 days) using bacterial cell.

\begin{tabular}{|c|c|c|c|c|c|}
\hline Mortar & Initial Mass & Mass after & \% Increment & Mass after & $\%$ Increment \\
\hline Samples & (g) & $30 \min (g)$ & in mass (g) & 72 h (g) & in mass \\
\hline Control & $735.5 \pm 0.4$ & $756.8 \pm 0.4$ & 2.9 & $790.5 \pm 0.6$ & 7.5 \\
\hline $10^{4}$ cells $/ \mathrm{ml}$ & $730.5 \pm 0.3$ & $747.0 \pm 0.2$ & 2.3 & $772.0 \pm 0.4$ & 5.7 \\
\hline $10^{5}$ cells $/ \mathrm{ml}$ & $733.2 \pm 0.5$ & $749.2 \pm 0.5$ & 2.2 & $767.6 \pm 0.4$ & 4.7 \\
\hline $10^{6} \mathrm{cells} / \mathrm{ml}$ & $720.3 \pm 0.4$ & $736.9 \pm 0.3$ & 2.3 & $765.2 \pm 1.0$ & 6.24 \\
\hline
\end{tabular}

Table 2. Sulphate resistant test with bacterial cells incorporated mortar samples.

\begin{tabular}{cccc}
\hline Mortar & Initial Mass $(\mathbf{g})$ & Final Mass (g) & Average \% Increment \\
\hline Samples & & & \\
\hline Control & $735.5 \pm 0.5$ & $796.8 \pm 0.6$ & 8.5 \\
$\mathbf{1 0}^{4}$ cells/ml & $731.6 \pm 0.4$ & $783.4 \pm 0.5$ & 7.1 \\
$\mathbf{1 0}^{5}$ cells/ml & $737.5 \pm 0.5$ & $770.5 \pm 0.5$ & 4.5 \\
$\mathbf{1 0}^{\mathbf{c}}$ cells/ml & $734.2 \pm 0.5$ & $789.2 \pm 0.5$ & 7.5 \\
\hline
\end{tabular}

the complete population diversity in them. Microbes commonly exist in milieus of varying complexity and diversity. Cultivation-based techniques have been found unable to accurately capture the true diversity of microbial communities. These have been overcome by applying molecular approaches that target the universally conserved 16S ribosomal RNA gene. It is thus imperative that further work in the field will yield fruition in going for 16S rRNA gene-based amplicon sequencing/complete metagenomic through Next-Gen Sequencing platforms to look up the diversity of the consortium in detail and the utility of many of the organisms from the same consortium.

\section{Acknowledgements}

The technical and experimental support rendered by the Biophysics Laboratory, Department of Physics, Jadavpur University, Raja Subodh Chandra Mallick Road, Kolkata: 700 032, West Bengal, India is gratefully acknowledged with our wholesome sincerity.

\section{References}

[1] López-López, O., Cerdán, M.E. and González-Siso, M.I. (2013) Hot Spring Metagenomics. Life, 3, 308-320. http://dx.doi.org/10.3390/life3020308

[2] Ghati, A., Sarkar, K. and Paul, G. (2013) Isolation, Characterization and Molecular Identification of Esterolytic Thermophilic Bacteria from an Indian Hot Spring. Curr Res Microbiol Biotechnol, 1, 196-202.

[3] Boskey, A.L. (2003) Biomineralization: An Overview. Connective Tissue Research, 44, 5-9. http://dx.doi.org/10.1080/03008200390152007

[4] Skinner, W.C.H. and Jahren, H.A. (2003) Biomineralization. In: Schlesinger, W.H., Ed., Treatise on Geochemistry, Elsevier, 117-184.

[5] Belkova, L.N. (2005) Biomineralization in Natural Environments: The Effect of Microorganisms Inhabiting Hot Spring Water and Biomats on Mineral Formation. Geophysical Research Abstracts, 7, 03264.

[6] Ehrlich, H.L. (1995) Geomicrobiology. Dekker M, New York.

[7] Ramachandran, S.K., Ramakrishnan, V. and Bang, S.S. (2001) Remediation of Concrete Using Microorganisms. ACI Materials Journal, 98, 3-9.

[8] Ghosh, P., Mandal, S., Chattopadhyay, B.D. and Pal, S. (2005) Use of Microorganism to Improve the Strength of Cement Mortar. Cement and Concrete Research, 35, 1980-1983. http://dx.doi.org/10.1016/j.cemconres.2005.03.005

[9] De Graef, B., De Windt, W., Dick, J., Verstraete, W. and De Belie, N. (2005) Cleaning of Concrete Fouled by Lichens with the Aid of Thiobacilli. Materials and Structures, 38, 875-882. 
[10] Bang, S.S., Galinat, J.K. and Ramakrishnan, V. (2001) Calcite Precipitation Induced by Polyurethane-Immobilized Bacillus pasteurii. Enzyme and Microbial Technology, 28, 404-409. http://dx.doi.org/10.1016/S0141-0229(00)00348-3

[11] Rodriguez-Navarro, C., Rodriguez-Gallego, M., Chekroun, K.B. and Gonzalez-Munoz, M.T. (2003) Conservation of Ornamental Stone by Myхососcus xanthus-Induced Carbonate Biomineralization. Applied and Environmental Microbiology, 69, 2182- 2193. http://dx.doi.org/10.1128/AEM.69.4.2182-2193.2003

[12] Ghosh, S., Biswas, M., Chattopadhyay, B.D. and Mandal, S. (2009). Microbial Activity on Microstructure of Bacteria Modified Mortar. Cement and Concrete Composites, 31, 93-98. http://dx.doi.org/10.1016/j.cemconcomp.2009.01.001

[13] Biswas, M., Majumdar, S., Chowdhury, T., Chattopadhyay, B.D., Mandal, S., Halder, U. and Yamasaki, S. (2010) Bioremediase a Unique Protein from a Novel Bacterium BKH1, Ushering a New Hope in Concrete Technology. Enzyme and Microbial Technology, 46, 581-587. http://dx.doi.org/10.1016/j.enzmictec.2010.03.005

[14] Majumdar, S., Sarkar, M., Chowdhury, T., Chattopadhyay, B.D. and Mandal, S. (2012) Use of Bacterial Protein Powder in Commercial Fly Ash Pozzolana Cements for High Performance Construction Materials. Open Journal of Civil Engineering (OJCE), 2, 218-228. http://dx.doi.org/10.4236/ojce.2012.24029

[15] Sarkar, M., Alam, N., Chaudhuri, B., Chattopadhyay, B.D. and Mandal, S. (2015) Development of an Improved E. coli Bacterial Strain for Green and Sustainable Concrete Technology. RSC Advances, 5, 32175-32182. http://dx.doi.org/10.1039/C5RA02979A

[16] Sarkar, M., Chowdhury, T., Chattopadhyay, B.D., Gachhui, R. and Mandal, S. (2014) Autonomous Bioremediation of a Microbial Protein (Bioremediase) in Pozzolana Cementitious Composite. Journal of Materials Science, 49, 4461-4468. http://dx.doi.org/10.1007/s10853-014-8143-1

[17] Ghosh, D., Bal, B., Kashyap, V.K. and Pal, S. (2003) Molecular Phylogenetic Exploration of Bacterial Diversity in a Bakreshwar (India) Hot Spring and Culture of Shewanella-Related Thermophiles. Applied and Environmental Microbiology, 69, 4332- 4336. http://dx.doi.org/10.1128/AEM.69.7.4332-4336.2003

[18] Chattopadhyay, B.D., Thakur, A.R., Poddar, R.K. and Dasgupta, D. (1993) Effect of Calcium ion on Methanosarcina Barkeri Ms. Ind J Expt Biol, 31, 738-742.

[19] Ausubel, F.M., Brent, R., Kingston, R.E., Moore, D.D., Seidman, J.G., Smith, J.A. and Struhl, K. (1994) Current Protocols in Molecular Biology. Wiley, New York.

[20] Felsenstein, J. (1985) Confidence Limits on Phylogenies: An Approach Using the Bootstrap. Evolution, 39, $783-791$. http://dx.doi.org/10.2307/2408678

[21] Neville, A.M. (1996) Properties of Concrete. 4th Edtion, Pearson Higher Education, Prentice Hall, Englewood Cliffs.

[22] Ferraris, C., Stutzman, P., Peltz, M. and Winpigler, J. (2005) Developing a More Rapid Test to assess sulfate resistance of Hydraulic Cements. Journal of Research of the National Institute of Standards and Technology, 110, 529-540. http://dx.doi.org/10.6028/jres.110.080 